\title{
Requirement of Sodium to Molted Laying Hens ${ }^{1}$
}

http://dx.doi.org/10.1590/1806-9061-2019-1102

\section{EAuthor(s)}

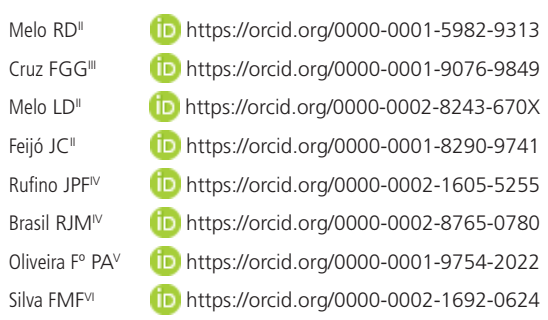

Part of master's degree dissertation of the first author.

" Graduate Program in Animal Science, College of Agrarian Sciences, Federal University of Amazonas, Manaus, Amazonas, Brazil.

III Department of Animal and Vegetable Production, College of Agrarian Sciences, Federal University of Amazonas, Manaus, Amazonas, Brazil.

Iv Graduate Program in Biodiversity and Biotechnology, College of Health Sciences, State University of Amazonas, Manaus, Amazonas, Brazil.

Graduate Program in Fisheries Science in the Tropics, College of Agrarian Sciences, Federal University of Amazonas, Manaus, Amazonas, Brazil.

v1 Animal Science Undergraduate, College of Agrarian Sciences, Federal University of Amazonas, Manaus, Amazonas, Brazil.

\section{-Mail Address}

Corresponding author e-mail address Ramon Duque Melo

College of Agrarian Sciences, Federal University of Amazonas, South Sector, University Campus, Av. General Rodrigo Octávio Jordão Ramos, 6200, Coroado I Manaus, Amazonas, Brazil, 69077-000 Phone: +55 xx 923305-1181 (R. 4082)

Email: ramon_duquemelo10@hotmail.com

\section{-Keywords}

Egg quality, eggshell, performance, sodium, weight gain.

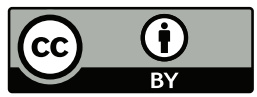

Submitted: 03/June/2019

Approved: 23/November/2019

\section{ABSTRACT}

The objective of this study was to determine the ideal requirement of sodium to molted laying hens. The experimental period lasted 105 days, divided into five periods of 21 days. Hisex White laying hens 150 with 84 weeks-of-age were used. The experimental design was completely randomized in a factorial scheme $(5 \times 3)$ with treatments constituted by five levels of sodium $(0.10,0.15,0.20,0.25$, and $0.30 \%)$ in the diets, and three postmolt stages (early $=21$ days, medium = 63 days, and final $=105$ days). Performance and egg quality results were evaluated by Tukey test at 5\%. Eggshell resistance and weight gain results were evaluated by polynomial regression at $5 \%$. Except the yolk height, all performance and egg quality variables were affected $(p<0.05)$ by the sodium levels and the hens' age postmolt. The level of $0.15 \%$ of sodium in diets to postmolt laying hens provided better performance and egg quality, especially in the eggshell. Higher levels of sodium negatively affected the performance and egg quality. Hens in the early stage of postmolt period presented better performance and egg quality. At long-term, the postmolt hens presented worst results.

\section{INTRODUCTION}

Molting is a natural phenomenon in wild and domestic birds, causing the replacement of feathers and involving reproductive quiescence. This period is responsible for a significant decline in egg production and provides the equivalent of a 'reproductive rest' to the birds (Khan et al., 2011). The low prices of eggs and spent flocks have resulted in the interest in replacing the natural molting process with the artificial one called induced molting (Berry, 2003).

Induced molting has become standard husbandry in many commercial egg operations. The main purpose of molting is to cease egg production in order for the hens to enter a nonreproductive state, which increases egg production and egg quality postmolt (Webster, 2003; Donaldson et al., 2005). Although several successful procedures exist to induce molting in laying hens, most of these techniques differ in several aspects (Hussein, 1996).

The most effective moulting procedures create the least amount of stress, produce a rapid moult, and bring the flock back into egg production quickly (North \& Bell, 1990). As a result, numerous studies have recognized the need for more information about molting procedures, timing and duration of the molting period, reproductive organ responses, bird behaviour, and nutritional requirements post molting (Wolford, 1984; Hussein, 1996). According to Teixeira \& Cardoso (2011), the nutritional readjustment of all nutrients of the diet is essential to a successful molt program. Studies about nutritional requirements for laying hens are frequently updated in the literature (Domingues et al., 2016). However, there is a great lack of information about requirements to molted laying hens. 
Studies investigating the sodium requirement are less found in the literature than other nutrients to laying hens in the first and second cycle. According to Borges (2001) and Borges et al. (2002), sodium, together with chlorine and potassium, present high metabolic activity in the acid-base balance, maintenance of the cellular osmotic pressure and metabolism of water in the tissues. These elements must be in constant balance so as not to compromise the good functioning of the enzymes responsible for several metabolic reactions. Both deficiency and excess of sodium in the poultry diets cause problems to the birds, mainly affecting the performance (Ribeiro, 2007; Lima et al., 2015).

Considering the above, the purpose of this study was to determine the ideal requirement of sodium to molted laying hens.

\section{MATERIAL AND METHODS}

This study was conducted in the facilities of Poultry Sector, College of Agrarian Sciences, Federal University of Amazonas, Manaus, Amazonas State, Brazil. The experimental procedures were approved by the Ethics Committee in Use of Animals (protocol number 041/2018) of the Federal University of Amazonas, Manaus, Amazonas, Brazil.

The experimental period lasted 105 days divided into five periods of 21 days. Birds were subjected to an adaptation period of seven days to feed and facilities. The aviary had galvanized wire cages $(1.00$ $\times 0.45 \times 0.50 \mathrm{~m}$ ), trough feeders, and nipple drinkers. A stocking density of $13.3 \mathrm{birds} / \mathrm{m}^{2}$ was used, with six birds per cage. Throughout the experimental period, 16 hours of light/day were provided to the birds (12 hours of natural +4 hours of artificial), with water and feed ad libitum. The temperature and air relative humidity were recorded twice a day (9 and 15 hours) from a digital hygrometer positioned at the height of the cages, obtaining averages results of $29.35^{\circ} \mathrm{C}$ and $63.57 \%$ respectively. Egg collection was also performed twice a day ( 9 and 15 hours).

From 80 to 83 wks of age, hens were submitted to a molt program using nonfeed removal method (Biggs et al., 2003; Mazzuco \& Hester, 2005) for 28 days. 150 Hisex White laying hens with 84 weeks of age were used. The birds were weighed at the beginning and at the end of the experimental period, presenting an initial average weight of $1.38 \pm 0.0019$ $\mathrm{kg}$, and a final average weight of $1.43 \pm 0.013 \mathrm{~kg}$. The experimental design was completely randomized in a factorial scheme $(5 \times 3)$ with treatments constituted by five levels of sodium $(0.10,0.15,0.20,0.25$, and $0.30 \%$ ) in the diets, and three postmolt stages (early
$=21$ days, medium $=63$ days, and final $=105$ days . Experimental diets (Table 1) were calculated according to the requirements provided by Rostagno et al. (2017) using the software SUPERCRAC (2008).

At the end of each period of 21 days, we calculated the feed intake (g/bird/day), egg production (\%), feed efficiency ( $\mathrm{kg}$ of feed used / kg of egg), feed efficiency ( $\mathrm{kg}$ of feed used / dozen eggs), and egg mass (g). At the end of each 21 days period, four eggs to each plot were randomly selected to evaluate egg weight (g), specific gravity $\left(\mathrm{g} / \mathrm{cm}^{3}\right)$, yolk (\%), albumen (\%), eggshell (\%), yolk height $(\mathrm{mm})$, albumen height $(\mathrm{mm})$, yolk color, eggshell thickness $(\mu \mathrm{m})$, Haugh unit, and eggshell resistance $(\mathrm{N})$.

The eggs were stored for one hour in room temperature and weighed using an electronic balance $(0.01 \mathrm{~g})$. The eggs were placed in wire baskets and immersed in buckets containing different levels of sodium chloride $(\mathrm{NaCl})$ with density variations from 1.075 to $1.100 \mathrm{~g} / \mathrm{cm}^{3}$ (interval of 0.005 ) to evaluate the specific gravity.

Then, the eggs were placed on a flat glass plate to determine albumen and yolk height, and yolk diameter using an electronic caliper. To separate albumen and yolk a manual separator was used. Each one was placed in a plastic cup and weighed in an analytical balance.

Eggshells were washed, dried in an oven $\left(50^{\circ} \mathrm{C}\right)$ for 48 hours, and weighed. Dry eggshells were used to determine the eggshell thickness using a digital micrometer. Average eggshell thickness was analyzed considering three regions: basal, meridional, and apical.

The yolk color was evaluated using a $\mathrm{ROCHE}^{\odot}$ colorimetric fan with a scale of 1 to 15 . Haugh unit was calculated using the egg weight and albumen height values in the formula $\mathrm{H}_{\text {unit }}=100 \times \log (\mathrm{H}+7.57$ $-1.7 \times$ W0.37), where $\mathrm{H}=$ albumen height $(\mathrm{mm})$, and $\mathrm{W}=$ egg weight $(\mathrm{g})$.

To determine the eggshell resistance, an electronic machine of mechanical (model Instron 5984) located in the Materials Laboratory of the Superior College of Technology of the State of Amazonas University, was used. This machine was connected to a computer, generating the power levels (represented in Newton) used to break the eggshell.

All data collected in this study were analyzed using the GLM procedure of SAS (Statistical Analysis System, v. 9.2) and estimates of treatments were subjected to ANOVA. Performance and egg quality results were evaluated by Tukey test. Eggshell resistance and weight gain results were evaluated by polynomial regression. Results were considered significant at $p \leq 0.05$. 
Table 1 - Experimental diets composition.

\begin{tabular}{|c|c|c|c|c|c|}
\hline \multirow[b]{2}{*}{ Ingredients } & \multicolumn{5}{|c|}{ Levels of sodium, $\%$} \\
\hline & 0.10 & 0.15 & 0.20 & 0.25 & 0.30 \\
\hline Corn $7.88 \%$ & 69.2669 & 69.1117 & 68.9566 & 68.8016 & 68.6464 \\
\hline Soybean meal $46 \%$ & 18.5293 & 18.5584 & 18.5875 & 18.6166 & 18.6457 \\
\hline Limestone & 9.6489 & 9.6486 & 9.6482 & 9.6478 & 9.6475 \\
\hline Dicalcium phosphate & 1.6723 & 1.6727 & 1.6731 & 1.6734 & 1.6738 \\
\hline Salt & 0.1686 & 0.2946 & 0.4206 & 0.5466 & 0.6726 \\
\hline PREMIX vitaminic/mineral & 0.5000 & 0.5000 & 0.5000 & 0.5000 & 0.5000 \\
\hline DL-Methionine 99\% & 0.2140 & 0.2140 & 0.2140 & 0.2140 & 0.2140 \\
\hline L-Lysine & 0.0372 & 0.0397 & 0.0421 & 0.0446 & 0.0471 \\
\hline L-Tryptophan & 0.0271 & 0.0276 & 0.0281 & 0.0285 & 0.0290 \\
\hline L-Threonine & 0.0073 & 0.0085 & 0.0098 & 0.0110 & 0.0124 \\
\hline Total & 100.00 & 100.00 & 100.00 & 100.00 & 100.00 \\
\hline \multicolumn{6}{|l|}{ Nutrients } \\
\hline Metabolizable energy, kcal. kg ${ }^{-1}$ & $2,799.92$ & $2,795.28$ & $2,790.65$ & $2,786.02$ & $2,781.38$ \\
\hline Crude Protein, \% & 14.500 & 14.500 & 14.500 & 14.500 & 14.500 \\
\hline Calcium, \% & 4.200 & 4.200 & 4.200 & 4.200 & 4.200 \\
\hline Available phosphorus, \% & 0.400 & 0.400 & 0.400 & 0.400 & 0.400 \\
\hline Sodium, \% & 0.100 & 0.150 & 0.200 & 0.250 & 0.300 \\
\hline Total methionine, \% & 0.422 & 0.422 & 0.422 & 0.422 & 0.422 \\
\hline Digestible methionine, $\%$ & 0.403 & 0.403 & 0.403 & 0.403 & 0.403 \\
\hline Digestible met. + cys., \% & 0.450 & 0.500 & 0.550 & 0.600 & 0.650 \\
\hline Digestible lysine, \% & 0.653 & 0.653 & 0.653 & 0.653 & 0.653 \\
\hline Digestible threonine, \% & 0.498 & 0.498 & 0.498 & 0.498 & 0.498 \\
\hline Digestible tryptophan, \% & 0.172 & 0.172 & 0.172 & 0.172 & 0.172 \\
\hline
\end{tabular}

' Guaranteed levels per kilogram of the product: Vitamin A 2,000,000 IU, Vitamin D3 400,000 IU, Vitamin E 2,400 mg, Vitamin K3 400 mg, Vitamin B1 100 mg, Vitamin B2 760 mg, Vitamin B6 100 mg, Vitamin B12 2,400 mcg, Niacin 5,000 mg, Calcium Pantothenate 2,000 mg, Folic acid 50 mg, Coccidiostat 12,000 mg, Choline 50,000 mg, Copper 1,200 mg, Iron 6,000 mg, Manganese 14,000 mg, Zinc 10,000 mg, lodine $100 \mathrm{mg}$. Selenium $40 \mathrm{mg}$. Vehicle q.s.p. 1,000 g.

\section{RESULTS}

All performance variables were affected $(p<0.05)$ by the sodium levels and the hens' age postmolt. Birds fed diets with $0.10 \%$ and $0.15 \%$ of sodium presented better egg production, feed efficiency, and egg mass. High levels of sodium significantly reduced the performance. In the final stage of postmolt period, the hens presented larger feed intake and lower egg production, which provide worst feed efficiency, and egg mass (Table 2).

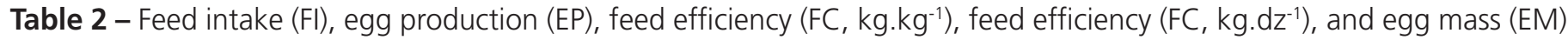
of postmolt laying hens fed diets with different levels of sodium.

\begin{tabular}{|c|c|c|c|c|c|}
\hline \multirow[b]{2}{*}{ Factors } & \multicolumn{5}{|c|}{ Variables } \\
\hline & $\mathrm{Fl}$ (g/bird/day) & $\operatorname{EP}(\%)$ & $\mathrm{FC}\left(\mathrm{kg} \cdot \mathrm{kg}^{-1}\right)$ & $\mathrm{FC}\left(\mathrm{kg} \cdot \mathrm{dz} z^{-1}\right)$ & EM (g) \\
\hline \multicolumn{6}{|l|}{ Sodium, \% } \\
\hline 0.10 & $106.29^{c}$ & $79.62^{\mathrm{ab}}$ & $2.07^{b}$ & $1.61^{b}$ & $51.53^{\mathrm{ab}}$ \\
\hline 0.15 & $111.06^{a}$ & $83.86^{a}$ & $2.07^{b}$ & $1.59^{b}$ & $53.89^{a}$ \\
\hline 0.20 & $107.49^{b}$ & $72.80^{b}$ & $2.39^{\mathrm{ab}}$ & $1.84^{\mathrm{ab}}$ & $46.69^{b}$ \\
\hline 0.25 & $107.24^{b}$ & $72.91^{b}$ & $2.47^{\mathrm{a}}$ & $1.83^{\mathrm{ab}}$ & $46.55^{b}$ \\
\hline 0.30 & $107.81^{b}$ & $72.64^{b}$ & $2.48^{a}$ & $1.89^{a}$ & $45.61^{b}$ \\
\hline \multicolumn{6}{|l|}{ Postmolt stage } \\
\hline Early & $100.59^{b}$ & $83.33^{a}$ & $2.06^{b}$ & $1.60^{b}$ & $53.89^{a}$ \\
\hline Medium & $110.79^{a}$ & $82.82^{a}$ & $2.13^{\mathrm{ab}}$ & $1.63^{b}$ & $52.96^{a}$ \\
\hline Final & $112.54^{\mathrm{a}}$ & $62.95^{\mathrm{b}}$ & $2.69^{a}$ & $2.02^{a}$ & $39.72^{b}$ \\
\hline Effect & & & value & & \\
\hline Sodium, \% & $0.01^{*}$ & $0.01^{*}$ & $0.01^{*}$ & $0.01^{*}$ & $0.01^{*}$ \\
\hline Postmolt stage & $0.01^{*}$ & $0.01^{*}$ & $0.01^{*}$ & $0.01^{*}$ & $0.01^{*}$ \\
\hline Interaction & $0.41^{\mathrm{ns}}$ & $0.24^{\text {ns }}$ & $0.16^{\text {ns }}$ & $0.15^{\text {ns }}$ & $0.16^{\text {ns }}$ \\
\hline CV (\%) & 6.40 & 12.87 & 6.54 & 5.84 & 13.26 \\
\hline
\end{tabular}

$\mathrm{CV}$ - Coefficient of variation; * Significant effect $(p<0.01)$; ns - non-significant. 
Egg weight and its main structures (yolk, albumen and shell) were affected $(p<0.05)$ by the sodium levels and hens' age. Birds fed diets with $0.10 \%$ and $0.15 \%$ of sodium produced heavier eggs, which reflected in larger percentages of its main structures. High levels of sodium significantly reduced its parameters (Table 3).
Hens in the early stage of postmolt period produced heavier eggs, with better percentages of its main structures. Medium stage of postmolt period also provided great results to egg weight and yolk percentage. From the increase of the hens' postmolt age, there was a reduction in its main structures, especially in the yolk and eggshell.

Table 3 - Egg weight, (EW), percentage of yolk (PY), percentage of albumen (PA), and percentage of eggshell (PS) of eggs from postmolt laying hens fed diets with different levels of sodium.

\begin{tabular}{|c|c|c|c|c|}
\hline \multirow[b]{2}{*}{ Factors } & \multicolumn{4}{|c|}{ Variables } \\
\hline & EW $(g)$ & Yolk, \% (\%) & Albumen (\%) & Eggshell (\%) \\
\hline \multicolumn{5}{|l|}{ Sodium, \% } \\
\hline 0.10 & $64.26^{\mathrm{ab}}$ & $29.04^{a}$ & $60.63^{a}$ & $10.00^{a}$ \\
\hline 0.15 & $64.74^{\mathrm{a}}$ & $29.11^{\mathrm{a}}$ & $60.74^{\mathrm{a}}$ & $10.11^{\mathrm{a}}$ \\
\hline 0.20 & $64.14^{\mathrm{ab}}$ & $28.12^{b}$ & $59.93^{b}$ & $9.89^{b}$ \\
\hline 0.25 & $63.26^{b}$ & $28.03^{b}$ & $59.19^{b}$ & $9.84^{b}$ \\
\hline 0.30 & $62.28^{c}$ & $27.99^{c}$ & $59.22^{b}$ & $9.65^{b}$ \\
\hline \multicolumn{5}{|l|}{ Postmolt stage } \\
\hline Early & $64.69^{a}$ & $60.51^{a}$ & $29.07^{a}$ & $10.32^{a}$ \\
\hline Medium & $63.98^{a}$ & $60.37^{a}$ & $28.33^{b}$ & $9.90^{b}$ \\
\hline Final & $62.91^{\mathrm{b}}$ & $58.73^{b}$ & $27.92^{c}$ & $9.23^{c}$ \\
\hline Effect & \multicolumn{4}{|c|}{$p$-value } \\
\hline Sodium, \% & $0.01^{*}$ & $0.04^{* *}$ & $0.01^{*}$ & $0.01^{*}$ \\
\hline Postmolt stage & $0.05^{* *}$ & $0.01^{*}$ & $0.01^{*}$ & $0.04^{* *}$ \\
\hline Interaction & $0.10^{\text {ns }}$ & $0.06^{\text {ns }}$ & $0.07^{\mathrm{ns}}$ & $0.12^{\text {ns }}$ \\
\hline CV (\%) & 4.08 & 3.70 & 4.75 & 5.43 \\
\hline
\end{tabular}

$\mathrm{CV}$ - Coefficient of variation; * Significant effect $(p<0,01) ;{ }^{* *}$ Significant effect $(p<0,05)$; ns - non-significant.

Except for the yolk height, all performance variables were affected $(p<0.05)$ by the sodium levels. Birds fed diets with $0.15 \%$ of sodium presented better egg quality. High levels of sodium significantly reduced the internal and external quality of the eggs (Table 4).
All egg quality variables were affected $(p<0.05)$ by the hens' postmolt age. Eggs from hens in the early stage of postmolt period presented better internal and external quality. From the increase of the hens' postmolt age, there was a significant reduction in the egg quality, especially the external quality.

Table 4 - Albumen height (AH), yolk height (YH), eggshell thickness (ST), specific gravity (SG), Haugh unit (HU), and yolk colour (YC) of eggs from postmolt laying hens fed diets with different levels of sodium.

\begin{tabular}{|c|c|c|c|c|c|c|}
\hline \multirow[b]{2}{*}{ Factors } & \multicolumn{6}{|c|}{ Variables } \\
\hline & $\mathrm{AH}(\mathrm{mm})$ & $\mathrm{YH}(\mathrm{mm})$ & $\mathrm{ET}(\mu \mathrm{m})$ & $\mathrm{SG}\left(\mathrm{g} / \mathrm{mL}^{3}\right)$ & $\mathrm{HU}$ & $Y C$ \\
\hline \multicolumn{7}{|l|}{ Sodium, \% } \\
\hline 0.10 & $7.76^{\mathrm{ab}}$ & 16.49 & $0.39^{a}$ & $1,085.58^{\mathrm{ab}}$ & $86.95^{\mathrm{ab}}$ & $5.68^{b}$ \\
\hline 0.15 & $7.92^{\mathrm{a}}$ & 16.56 & $0.39^{a}$ & $1,086.08^{a}$ & $88.33^{a}$ & $5.78^{a}$ \\
\hline 0.20 & $7.59^{b}$ & 16.72 & $0.38^{b}$ & $1,084.91^{b}$ & $85.58^{b}$ & $5.66^{b}$ \\
\hline 0.25 & $7.45^{b}$ & 16.65 & $0.37^{c}$ & $1,083.66^{b}$ & $84.90^{c}$ & $5.65^{b}$ \\
\hline 0.30 & $7.31^{c}$ & 16.55 & $0.37^{c}$ & $1,065.91^{c}$ & $84.13^{c}$ & $5.23^{c}$ \\
\hline \multicolumn{7}{|l|}{ Postmolt stage } \\
\hline Early & $7.73^{a}$ & $17.85^{a}$ & $0.40^{a}$ & $1,088.15^{\mathrm{a}}$ & $86.96^{a}$ & $6.12^{a}$ \\
\hline Medium & $7.54^{b}$ & $16.20^{\mathrm{b}}$ & $0.40^{\mathrm{a}}$ & $1,085.50^{b}$ & $85.62^{b}$ & $5.82^{b}$ \\
\hline Final & $7.54^{b}$ & $15.72^{c}$ & $0.34^{b}$ & $1,070.05^{c}$ & $85.36^{b}$ & $4.87^{c}$ \\
\hline Effect & \multicolumn{6}{|c|}{$p$-value } \\
\hline Sodium, \% & $0.03^{* *}$ & $0.86^{\mathrm{ns}}$ & $0.02^{* *}$ & $0.01^{*}$ & $0.01^{*}$ & $0.01^{*}$ \\
\hline Postmolt stage & $0.04^{* *}$ & $0.01^{*}$ & $0.01^{*}$ & $0.01^{*}$ & $0.02^{* *}$ & $0.01^{*}$ \\
\hline Interaction & $0.08^{\text {ns }}$ & $0.13^{\text {ns }}$ & $0.18^{\text {ns }}$ & $0.12^{\text {ns }}$ & $0.17^{\text {ns }}$ & $0.14^{\text {ns }}$ \\
\hline CV $(\%)$ & 7.37 & 3.71 & 5.84 & 2.89 & 3.89 & 7.24 \\
\hline
\end{tabular}

CV - Coefficient of variation; * Significant effect $(p<0,01) ;{ }^{* *}$ Significant effect $(p<0,05)$; ns - non-significant. 
Melo RD, Cruz FGG, Melo LD, Feijó JC, Rufino JPF, Brasil RJM, Oliveira $\mathrm{F}^{\circ} \mathrm{PA}$, Silva FMF
Sodium levels significantly affected $(p<0.05)$ the eggshell resistance (Table 5 ) both in the vertical and horizontal positions. Birds fed diets with $0.15 \%$ of sodium produced the most resistant eggshells in the vertical position $\left(y=-0.8479 x^{2}+0.25381 x+49.338\right.$ $\left.\mathrm{R}^{2}=0.73\right)$, however most fragile in the horizontal position $\left(y=-0,8121 x^{2}+0,25119 x+39,004 R^{2}=\right.$ $0,85)$.

Table $\mathbf{5}$ - Resistance of eggshells in vertical (REV) and horizontal (REH) positions of eggs from postmolt laying hens fed diets with different levels of sodium.

\begin{tabular}{lcc}
\hline Sodium, \% & REV, N & REH, N \\
\hline 0.10 & 35.33 & 39.83 \\
0.15 & 47.97 & 27.74 \\
0.20 & 31.18 & 33.64 \\
0.25 & 30.98 & 33.46 \\
0.30 & 32.67 & 36.86 \\
\hline$p$-value & 0.05 & 0.02 \\
\hline Effect & $\mathrm{Q}$ & $\mathrm{Q}$ \\
\hline CV (\%) & 2.09 & 8.83 \\
\hline
\end{tabular}

CV - Coefficient of variation. $p$-value - Coefficient of Probability. Q - Quadratic effect.

Sodium levels significantly affected $(p<0.05)$ the weight gain (Table 6) of postmolt laying hens. Birds fed diets with $0.10 \%$ of sodium present a lower weight gain $\left(y=-1,3936 x^{2}+0,70316 x+11,7 R^{2}=0,89\right)$. All postmolt hens presented weight gain, regardless of the sodium level used in the diets.

Table $\mathbf{6}$ - Weight gain of postmolt laying hens fed diets with different levels of sodium.

\begin{tabular}{lc}
\hline Sodium, $\%$ & Weight gain, $\%$ \\
\hline 0.10 & 1.90 \\
0.15 & 11.13 \\
0.20 & 11.63 \\
0.25 & 11.70 \\
0.30 & 11.39 \\
\hline$p$-value & 0.01 \\
\hline Effect & $\mathrm{Q}$ \\
\hline CV $(\%)$ & 7.56 \\
\hline
\end{tabular}

CV - Coefficient of variation. $p$-value - Coefficient of Probability. Q - Quadratic effect.

\section{DISCUSSION}

The increase levels of sodium caused a significant effect on the birds' performance. Sodium levels above $0.20 \%$ caused a significant lower in feed intake, consequently affecting the feed efficiency, egg production and egg mass. These results corroborate Murakami et al. (2003) and Ribeiro et al. (2008), where the authors reported that sodium levels between 0.15 to $0.20 \%$ were sufficient to provide a better requirement to postmolt hens, presenting a better performance and egg quality, especially the eggshell.
The same authors also commented that both deficit and higher sodium levels are adverse to hens, providing worst results.

High levels of sodium in the poultry diets tend to stimulate an excessive water intake, restricts the feed intake, negatively interferes on respiratory alkalosis, electrolyte balance and nutrient absorption by the sodium and potassium pump, generating significant economic losses to the hens (Ribeiro, 2007; Lima et al., 2015). The literature presents a great variance in the requirement of sodium to molted laying hens, where Fassani et al. (2002) suggested values between 0.19 to $0.22 \%$, Murakami et al. (2003) proposed $0.13 \%$, and Rodrigues et al. (2004) recommended $0.25 \%$. Murakami etal. (2003), and Lima etal. (2015) attributed this significant variation to the use of birds of different strains, ages, environmental conditions among other factors that may influence the physiological response of the hens. However, all authors reported that the performance and the quality of the eggs are negatively affected by high levels of sodium.

The eggshell is the most affected parameter by the sodium levels variation in the diets due to acidbase balance to be an important factor in the eggshell formation (Mongin, 1968). Hall \& Helbacka (1959) suggested that the deposition of calcium carbonate in the eggshell is dependent upon blood $\mathrm{pH}$, where the ion sodium is the most important regulator. In this sense, the metabolic acidosis and alkalosis could be produced by altering the dietary sodium to chloride ratio, regardless of the total concentration of these two ions in the diet (Cohen et al., 1972). Frank \& Burger (1965) reported that an ideal sodium supplementation result in thicker eggshells. Miles \& Harms (1982) indicated that a correct supplementation of sodium associated with the calcium content in the diet result in an increase on egg specific gravity.

According to Gal-Gaber et al. (2003) and Costa et al. (2012) excessive sodium consumption may affect the kinetic behavior of the small intestine of birds, possibly reducing the absorption, because the affinity of the sodium pump is reduced with excess of sodium in the organism. Thus, less calcium will be absorbed and could be available to eggshell formation, producing eggs with a more fragile shell, where the internal contents will be more susceptible to the action of microorganisms.

On the other hand, our results pointed that the postmolt stage also affected the performance and egg quality. After the molting process, the birds tend to presented great performance and egg quality due to 
Melo RD, Cruz FGG, Melo LD, Feijó JC, Rufino JPF, Brasil RJM, Oliveira $\mathrm{F}^{\circ} \mathrm{PA}$, Silva FMF ovarian and oviducal regression (Gongruttananun et al., 2013; Gongruttananun \& Saengkudrua, 2016). However, approaching 100 weeks, there was a significant reduction on performance and egg quality. Normally, the molt procedure cause a significant increase on performance and egg quality at shortterm and these indexes tend to decrease according to the age of the bird due to the natural wear caused by constant egg production in industrial scale (Wu et al., 2007). Physiologically, there are great wear on oviduct tissues, and difficulty to absorb the nutrients and its transfer to the egg's composition (Newman and Lesson, 1999; Bar et al., 2001; Heflin et al., 2018; Elhamouly et al., 2019).

Different strains may to present different responses on performance after molt, especially on laying hens and semi-heavy hens (Said et al., 1984; Gongruttananun et al., 2017; Hu et al., 2019). There is very limited literature about the performance, egg composition, egg solids, egg quality, and profits of postmolt hens (Wu et al., 2007), especially at long-term, a period near or exceeding to 100 weeks. An induced molting not only may improve performance and eggshell quality, but also increase profits by optimizing the use of replacement pullets on commercial layer farms (Lee, 1982; Barker et al., 1981; Bell, 2003; Mazzuco et al., 2011; Gongruttananun, 2018) proving the importance to understand its effect at long-term.

Wilson et al. (1967) studying several methods of inducing a molt and subsequent rest period, observed that molted hens present a better performance and shell thickness at short-term without affect the egg weight and albumen quality, regardless to the molt process used. However, this effect significantly reduces at long-term, where the hens present clear signals of fatigue due to the old age (Chanaksorn et al., 2019).

At the end of the experimental period, when the hens presented nearly 100 weeks, all birds presented a gain in the weight. However, the level of sodium in the diet directly influenced this parameter, where laying hens fed diets with the lower sodium level present a significant lower weight gain. Normally, a reduction in body weight of 15 to $30 \%$ during the molt is necessary to maximize the performance of laying hens at the second cycle (Barker et al., 1981). The birds lose this weight during the molt period and gain (recover) at a faster rate after the molt (Wilson et al., 1967). McDaniel (1985) reported that the lightest birds before molt have a tendency to gain the greatest percent weight from the end of the molt to the onset of egg production. In this sense, Buhr and Cunningham (1994) also commented that during the postmolt period the body weight gain increased, with the $15 \%$ weight loss groups maintaining a slightly heavier body weight throughout the postmolt period. The same authors affirmed that the molt method directly affect the body weight, performance, and egg quality.

\section{CONCLUSIONS}

It was concluded that the level of $0.15 \%$ of sodium in diets to postmolt laying hens provided better performance and egg quality, especially in the eggshell. Higher levels of sodium negatively affected the performance and egg quality. Hens in the early stage of postmolt period presented better performance and egg quality. In the long-term, the postmolt hens presented worst results.

\section{REFERENCES}

Bar A, Razaphkovsky V, Wax E, Malka Y. Effect of age at molting on postmolting performance. Poultry Science 2001;80:874-878.

Barker M, Brake J, McDaniel GR. The relationship between body weight loss during an induced molt and post-molt egg production, egg weight, and shell quality in caged layers. Poultry Science 1981;62:409-413.

Bell DD. Historical and current molting practices in the U.S. table egg industry. Poultry Science 2003;82:965-970.

Berry WD. The physiology of induced moulting. Poultry Science 2003; 82:971-980.

Biggs PE, Douglas MW, Koelkebeck KW, Parsons CM. Evaluation of nonfeed removal methods for molting programs. Poultry Science 2003;82:749753.

Borges SA, Laurentiz AC, Araújo LF, Araújo CSS, Maiorka A, Ariki J. Effect of crude protein and diferent balance eletrolytic of the diets on broilers performance during the starter period. Revista Brasileira de Ciência Avícola 2002;4(2): 155-161

Borges SA. Balanço eletrolítico e sua interrelação com o equilíbrio ácidobase em frangos de corte submetidos a estresse calórico [thesis]. Jaboticabal (SP): Universidade Estadual Paulista; 2001.

Buhr RJ, Cunninghan DL. Evaluation of molt induction to body weight loss fifteen or twenty-five percent by feed removal, daily limited, or alternative-day feeding of molt feed. Poultry Science 1994;73:14991510 .

Chanaksorn M, Boonkaewwan C, Kayan A, Gongruttananun N. Evaluation of molt induction using cassava meal varying the length of feeding period in older (90 week) laying hens. Poultry Science 2019;98:41314139.

Cohen I, Hurwitz S, Bar A. Acid-base balance and sodium-to-chloride ratio in diets of laying hens. Journal of Nutrition 1972;102:1-8.

Costa FGP, Figueiredo-Lima DF, Lima MR, Pinheiro SG, Goulart CC, Silva JHV, Baraldi-Artoni SM, Barreiro FR, Givisiez PEN. Sodium levels for Japanese quail at initial phases. Poultry Science 2012;91(5):1128-1134.

Domingues CHF, Sgavioli S, Praes MFFM, Santos ET, Castiblanco DMC, Petrolli TG, Duarte KF, Junqueira OM. Lysine and methionine+cystine on performance and egg quality of laying hens: Review. PUBVET 2016;10(6):487-493. 
Melo RD, Cruz FGG, Melo LD, Feijó JC, Rufino JPF, Brasil RJM, Oliveira F' PA, Silva FMF
Donalson LM, Kim WK, Woodward C, Herrera P, Kubena LF, Nisbet DJ, Ricke SC. Utilizing different ratios of alfalfa and layer ration for molt induction and performance in commercial laying hens. Poultry Science 2005;84(3):362-369.

Elhamouly M, Nii T, Isobe N, Yoshimura Y. Age-related modulation of the isthmic and uterine mucosal innate immune defense system in laying hens. Poultry Science 2019;98:3022-3028

Fassani EJ, Bertechini AG, Brito JAG, Kato RK, Geraldo A. Utilização de diferentes níveis de suplementação de sódio para poedeiras comerciais no segundo ciclo de produção. Revista Brasileira de Ciência Avícola 2002;4(3):235-241.

Frank FR, Burger RE. The effect of carbon dioxide inhalation and sodium bicarbonate ingestion on egg shell deposition. Poultry Science 1965:44:1604-1606

Gal-Garber O, Mabjeesh SJ, Sklan D. Nutrient trans-port in the small intestine: $\mathrm{Na}+, \mathrm{K}+$-ATPase expression and activity in the small intestine of the chicken as influenced by dietary sodium. Poultry Science 2003;82:1127-1133

Gongruttananun N, Kochagate P, Poonpan K, Yu-nun N, Aungsakul J, Sopa $\mathrm{N}$. Effects of an induced molt using cassava meal on body weight loss, blood physiology, ovarian regression, and postmolt egg production in late-phase laying hens. Poultry Science 2017; 96:1925-1933.

Gongruttananun N. Induced molt using cassava meal. 2. Effects on eggshell quality, ultrastructure, and pore density in late-phase laying hens. Poultry Science 2018; 97:1050-1058.

Gongruttananun, N, Guntapa P, Saengkudrua K. The effects of a shortterm molt method using cassava meal, broken rice, or corn on ovarian regression, bone integrity, and post molt egg production and quality in older (95 wk) laying hens. Poultry Science 2013;92:2798-2807.

Gongruttananun, N, Saengkudrua K. Responses of laying hens to induce molting procedures using cassava meal of variable length with or without recovery period. Agriculture and Natural Resources 2016:50:400-407.

Hall KN, Helbacka NV. Improving albumen quality. Poultry Science 1959; 38:111-114.

Heflin LE, Malheiros R, Anderson KE, Johnson LK, Raatz SK. Mineral content of eggs differs with hen strain, age, and rearing environment. Poultry Science 2018;97:1605-1613.

Hu JY, Hester PY, Xiong Y, Gates RS, Makagon MM, Cheng HW. Effect of cooled perches on the efficacy of an induced molt in White Leghorn laying hens previously exposed to heat stress. Poultry Science 2019;98:4290-4300.

Hussein AS. Induced moulting procedures in laying fowl. World's Poultry Science Journal 1996; 52(2):175-187.

Khan RU, Nikousefat Z, Javdani M, Tufarelli V, Laudadio V. Zinc-induced moulting: production and physiology. World's Poultry Science Journal 2011; 67(3):497-506.

Lee K. Effects of forced moult period on post-moult performance of Leghorn hens. Poultry Science 1982;61:1594-1598.

Lima HJD, Barreto SLT, Paula E, Dutra DR, Costa SL, Abjaude WS. Níveis de sódio na ração de codornas japonesas em postura. Revista Brasileira de Saúde e Produção Animal 2015; 16:73-81.
Mazzuco H, Avila VS, Coldebella A, Mores R, Jaenisch FRF, Lopes LS. Comparison of the effect of different methods of molt: Production and welfare evaluation. Poultry Science 2011; 90:2913-2920.

Mazzuco H, Hester PY. The effect of an induced molt using a non fasting program on bone mineralization of White Leghorns. Poultry Science 2005; $84: 1483-1490$.

McDaniel GR. Factors affecting broiler breeder performance 6 . The relationship of premolt performance to postmolt performance. Poultry Science 1985; 64(12):2267-2272.

Miles RD, Harms RH. Relationship between egg specific gravity and plasma phosphorus from hens fed different dietary calcium, phosphorus and sodium levels. Poultry Science 1982; 61:175-177.

Mongin P. Role of acid-base balance in physiology of egg shell formation. World Poultry Science Journal 1968;24:200-230.

Murakami AE, Figueiredo DF, Peruzzi AZ, Franco JRG, Sakamoto MI. Níveis de sódio para poedeiras comerciais no primeiro e segundo ciclos de produção. Revista Brasileira de Zootecnia 2003;32(6):1674-1680.

Newman S, Leeson S. The effect of feed deprivation and subsequent refeeding on the bone characteristics of aged hens. Poultry Science 1999;78:1658-1663.

Ribeiro MLG. Níveis de sódio na ração de frangas e de galinhas poedeiras durante o primeiro e o segundo ciclo de postura [dissertation]. João Pessoa (PB): Universidade Federal da Paraíba; 2007.

Rodrigues $E A$, Junqueira $O M$, Valério $M$, Andreotti $M O$, Cancherini LC, Faria DE, Filardi RS. Níveis de sódio em rações de poedeiras comerciais no segundo ciclo de postura. Revista Brasileira de Zootecnia 2004;33(2):391-396.

Rostagno HS, Albino LFT, Hannas MI, Donzele JL, Sakomura NK, Costa FGP, Saraiva A, Teixeira ML, Rodrigues PB, Oliveira RF, Barreto SLT, Brito CO. Tabelas brasileiras para aves e suínos: composição de alimentos e exigências nutricionais. $4^{\text {th }}$ ed. Viçosa: UFV; 2017.

Said NW, Sullivan TW, Bird HR, Sunde ML. A comparison of the effect of two force molting methods on performance of two commercial strains of laying hens. Poultry Science 1984; 63:2399-2403.

Teixeira RSC, Cardoso WM. Forced molting in modern poultry production. Revista Brasileira de Reprodução Animal 2011;35:444-455.

Webster $A B$. Physiology and behavior of the hen during induced molt. Poultry Science 2003; 82:992-1002.

Wilson HR, Fry JL, Harms RH, Arrington LR. Performance of hens molted by various methods. Poultry Science 1967; 46(6):1406-1412.

Wolford $\mathrm{JH}$. Induced moulting in laying fowls. World's Poultry Science Journal 1984;40(01): 66-73.

Wu G, Gunawardana P, Bryant MM, Voitle RA, Roland DA. Effect of molting method and dietary energy on postmolt performance, egg components, egg solid, and egg quality in bovans white and dekalb white hens during second cycle phases two and three. Poultry Science 2007; 86(5):869-876. 
